\title{
Agrarni institut osniva časopis Sociologija sela 1963. godine
}

\section{Vladimir Stipetić \\ Hrvatska akademija znanosti i umjetnosti, Zagreb, Hrvatska}

Došavši kao docent u Zagreb (prosinac 1960. godine), odmah sam dobio obvezu pripremiti predavanja iz Ekonomike agrara (s kolegom Ivom Žuvelom). On je već imao predavanja na tu temu (predavao je, osim toga, u školi u Novom Marofu ekonomiku agrara i tamo objavio skripta na više stotina stranica). Mirković se povukao s tog predmeta (nakon napada na njega u Ekonomskoj politici i drugim partijskim glasilima zbog njegova članka o „novoj privrednoj politici“ u Vjesniku u srijedu, u kojem je kritizirao i termin s kojim je bio lansiran i nedosljednosti pri provođenju proklamiranih načela). Predavao je od 1958. godine Ekonomsku historiju naroda Jugoslavije (Dragica Rogić, docentica, sudjelovala je s njim u nastavi), a ostale predmete iz tada suvremene ekonomike prepustio je nastavnicima (Farkaš je tako predavao ekonomiku industrije, vanjsku trgovinu Srđan Srdar itd.).

No samo sam jednu godinu dijelio taj kolegij sa Žuvelom. Mirković je, naime, dobio mandat za osnivanje Ekonomskog fakulteta u Rijeci, a kako je tamo bilo malo ekonomista koji su se mogli tada natjecati za nastavnička zvanja, Žuvela je od Mirkovića dobio mandat dekana na tom novoosnovanom fakultetu. Korčulanin je imao razumijevanja za maritimne aktivnosti (napisao je sjajnu knjigu o ribarenju, a mnogo je radova imao i iz ekonomike pomorstva). Tako sam od 1961./1962. sam predavao ekonomiku poljoprivrede. Dobro sam, dakako, poznavao literaturu iz uže materije (morao sam je proći kad sam pisao svoj doktorat), ali sam osjećao da sam neusporedivo slabiji u sociologiji sela i seljaštva ${ }^{1}$.

Zato sam se odlučio upoznati s radom Agrarnog instituta na sociologiji sela, koji je krenuo upravo tim putom. Primio me je tadašnji direktor Branko Karanović (1927. - 1964.), Bjelovarčanin, koji je svojim radom u Zadružnom savezu svoje (pravničko) obrazovanje sjajno dopunio. U Amruševoj ulici, gdje je bio smješten, Institut je imao lijepe prostorije: biblioteka je bila skromna, ali je kadar okupljen radi socioloških i

${ }^{1}$ U svojoj disertaciji navodim kako sam koristio Dubićevu Sociologiju sela, objavljenu 1941. godine u Splitu, ali i danas smatram da mu je daleko bolja studija o Istraživanju seljačkih gospodarstava koju je izdao 1934. godine u Križevcima. Obrnuto, isticao sam tu radove Antuna Radića i Josipa Predaveca koji su svoja izvanredna sociološka opažanja objavljivali u knjigama i člancima. 
agrarnih pitanja bio sjajan. Najveći kapital koji je Agrarni institut posjedovao bili su ljudi. Svi su oni već bili tamo zaposleni kad sam postao direktor tog Instituta, pa sam se divio Karanoviću kako je našao tolike mlade talente za svoj Agrarni institut. Bili su to beziznimno mladi mladi od 30 godina sa sjajnim intelektualnim potencijalom. Svi će se oni kasnije afirmirati i dokazati kao izvanredan znanstveni potencijal. To su bili: sociolog Stipe Šuvar (kasniji ministar, pa i predsjednik Jugoslavije), pravnik Zvonimir Baletić (koji će doktorirati, prijeći na Pravni fakultet, potom na Fakultet političkih znanosti i postati akademik), sociolog Svetozar Livada (ostat će privržen Agrarnom institutu sve do svog odlaska u mirovinu), Vlado Cvjetićanin (koji je krajem šezdesetih godina, nažalost, napustio tematiku sociologije sela), Vlado Puljiz (koji će kasnije biti redoviti profesor na Sveučilištu u Zagrebu i baviti se socijalnom politikom) i mnogi drugi. Spomenut ću i tajnika Agrarnog instituta Đuru Lazića, tihog i povučenog, ali iznimno učinkovitog u provođenju zaključaka kolektiva ili stavova direktora.

Dopao mi se taj kolektiv mladih, marnih i sposobnih, s tematikom koja je dotad bila slabo obrađivana. Bila je to prostrana, neuzorana ledina koja je vapila za obradom. Kad je Branko Karanović 1962. godine imenovan za generalnog direktora Jugoslavenske poljoprivredne, banke pozvao me i rekao kako on ne vidi boljeg nasljednika od mene na mjestu direktora Instituta. „Razgovarao sam“, reče, „i s Vladimirom Bakarićem i on se slaže da bi Tebi tu bilo pravo mjesto." Nisam otprve na to pristao; bio sam već postavljen za direktora novoosnovanog Ekonomskog instituta JAZU, izabrao sam četiri suradnika s kojima sam se već uputio u poslove i sad, najednom, trebao bih to sve napustiti. I što će reći Mijo Mirković koji stoji iza svega toga? Moje je kolebanje trajalo nekoliko mjeseci, na tri se „tezge“ nije moglo (fakultet plus dva instituta). U odluci mi je pomogla Mirkovićeva teška bolest, od koje je i umro (u veljači 1963. godine). Prešao sam u Agrarni institut, napustio onaj u JAZU-u (institut je nakon Mirkovićeve smrti bio „likvidiran“, pri čemu su svi zaposleni dobili poslove koje su htjeli) i punim se jedrima bacio u razvoj Agrarnog instituta.

Jedan od mojih prvih poslova u Agrarnom institutu bio je izdavanje časopisa. Formirala se i buduća redakcija koju su činili V. Cvjetićanin, S. Livada, P. Marković, M. Martić, V. Stipetić i S. Šuvar. Taj je brojčano mali kolektiv izradio i platformu o tematici sadržaja časopisa. Tu je bilo rečeno, između ostalog, da će časopis:

- objavljivati radove o socijalnim i kulturnim obilježjima i preobražajima jugoslavenskog sela, a prvenstveno pri tome o zemljovlasničkim odnosima, socijalnoj dinamici selo - grad, oblicima života na selu, socijalnom i kulturnom stanju sela i aspiracijama mlađeg naraštaja, ocjenama prilika od starijih; promjenama u obitelji i braku i korištenju slobodnog vremena

- $\quad$ procjenjivati nasljeđe naše ruralne sociologije i stvarati uvjete za njen razvoj u suvremenim uvjetima

- informirati o mjestu, ulozi, postupcima i djelima ruralne sociologije u drugim zemljama (jer smo smatrali da su transformacija seljaštva i napuštanja sela univerzalni, gotovo svjetski proces)

- raspraviti metodološka pitanja (primjerice: kako doći do dominantnog stava seoske populacije; koji odnos imati između terenskog i anketnog istraživanja; što je uloga statistike; koje i koliko monografija sela itd.) 
- $\quad$ pratiti i komentirati mjere agrarne politike i njihov odraz na selu

- informirati o istraživačkim projektima na području ruralne sociologije (jednako ukazati na početne korake, kao i na rezultate istraživanja)

- pratiti formiranje ruralnih sociologa u nas i u inozemstvu te način prenošenja spoznaja ruralne sociologije u druga zvanja (od agronoma i veterinara do ekonomista i politologa)

- recenzirati periodiku i drugu literaturu iz ruralne sociologije - kod nas i u svijetu.

Taj program - deziderata - bio je upućen mnogim institucijama, s molbom da dadu i određene primjedbe i, eventualno, pripreme priloge za prvi broj časopisa (koji se trebao pojaviti u rujnu 1963. godine).

Odaziv je bio velik, vjerojatno i zbog toga što smo poziv i obavijest uputili svim stručnjacima koji su se tada bavili ili su nekoć radili na sociologiji sela, ali i onima koji su politički radili na selu i bili u doticaju sa stanovništvom. Zato je odaziv bio velik i nije bilo teško popuniti već prve brojeve iznimno kvalitetnim prilozima. Kao dobri „domaćini“ u prvim smo brojevima časopisa dali prednost ljudima koji nisu radili u samom Institutu jer smo željeli dokazati kako smo otvoreni za sve koji se tom problematikom bave.

To je i razlog zbog čega su u prve tri godine u Sociologiji sela svoj prostor našli mnogi kojima drugi časopisi tada nisu bili skloni. U njemu su, za prve tri godine, objavljivali i istaknuti pisci s cijelog područja bivše države. Navest ćemo ih abecednim redom: Bićanić, Rudolf; Bogdanović, Jovan; Bogdanović, Miloš; Božić, Ljubo; Erlich, Vera; Jerovšek, Janez; Klauzer, Ivan; Kostić, Cvetko; Krušovec, Stane; Marković, Darinka; Marković, Petar; Martić, Mirko; Milutinović, Milan; Mlinar, Zdravko; Perić, Ivan; Prokić, Dragana; Radovanović, Borislav; Ružić, Zdenko; Todorović, Aleksandar.

No još je veći dojam ostavljalo praćenje inozemnih časopisa koji su se bavili sociologijom sela, ali i ekonomikom poljoprivrede ${ }^{2}$.

Takvo praćenje stvaralo je i kod suradnika i kod čitatelja uvjerenje kako se u suštini radi o priključenju hrvatske znanosti jednom globalnom problemu s kojim se sukobljava čovječanstvo.

Međutim iznimna korist od upoznavanja javnosti i stručnjaka s nalazima inozemnih ruralnih sociologa bila je u samom Agrarnom institutu dopunjena stalnom izmjenom

2 Tako su bili prikazivani sljedeći časopisi, gotovo u svakom broju: Etudes rurales (francuski), Rural Sociology (engleski), Archives europeennes de sociologie, Kulturni život (Beograd), Sociology Ruralis, World Agricultural Economics and Rural, Sociology Abstracts (London), Zemedelska ekonomika (Prag), Wies wspolczsesna (Varšava), Ekonomika poljoprivrede (Beograd), The Polish Sociological Bulletin, Naše teme (Zagreb), Sociologie a historie zemedelstvi (Prag), Przeglad Socjologiczny (Varšava), Revue française de sociologie (Pariz) i Geografski vestnik (Ljubljana). 
spoznaja o procesima koji se odvijaju na selu. Svi su sociolozi u Institutu, naime, putovali po seoskim područjima Hrvatske i odatle donosili ne samo vijesti već i kritička opažanja o stanju u selu. Narastanje broja gospodarstava seljaka-radnika koji su nerijetko sate gubili u pješačenju ili prijevozu do mjesta rada, uz nesposobnost tako premorenog radnika da preuzme nekadašnje poslove oko poljoprivredne proizvodnje, pretvaralo se sve više u permanentni problem hrvatske poljoprivrede 3 . Tako je masovni egzodus poljoprivrednika sa sela imao svoj sociološki, ali i ekonomski sklop.

Ruralni sociolozi u Agrarnom institutu suočavaju se tako s prvom generacijom politički osviještenih seljaka, koji su tek početkom 20. stoljeća počeli sudjelovati u političkom životu ${ }^{4}$. Seljačka populacija, koju oni proučavaju, upoznala je prije II. svjetskog rata brojne pohode agitatora i demagoga koji su joj davali jeftina obećanja tražeći izbornu podršku; ta se generacija naslušala govora o seljačkoj državi, pravdi, poštenju i napretku, što se nije ostvarilo ni kada bi oni bili izabrani. Narodnjački pokreti i njihove ideologije vjerovale su u mogućnost rekonstrukcije seljačkih društava, cvale su te ideologije svugdje gdje je politički razvoj bio brži od ekonomskog. No istinski subjekt realizacija tih ideala seljaštvo je postalo tek tijekom rata 1941. - 1945. godine kad je ono dalo masovnu podršku promjenama. Rat je tijekom četiri godine odbacio stare odnose i shvaćanja. Seljak je definitivno tada prestao biti patrijarhalna, u prošlosti zatvorena osoba, postao je subjekt, a ne objekt političara. Bio je spreman napustiti selo i odnose koje je ono dotad pretpostavljalo.

No vrlo brzo (nakon agrarne reforme i kolonizacije 1945. - 1948.) političko rukovodstvo napušta demokratski savez sela i grada i forsira prisilni otkup i kolektivizaciju, pri čemu je seljaštvo bilo lišeno ne samo demokratskih prava već i vlastita dohotka i imovine. Postojanje tog sustava, što je trajalo od 1946. do 1953. godine, ostavilo je selo duboko razočarano, poniženo i uvrijeđeno te još pored toga osiromašeno. Bio je slomljen „opjevani“ savez radnika i seljaka, a njegovoj obnovi nije bitnije pomoglo ni postupno napuštanje modela prvobitne akumulacije (koji je djelovao slijedeći postavke sovjetskog ekonomista Preobraženskog). U tim uvjetima istraživanje Sociologije sela, koje provodi mala grupa istraživača u Agrarnom institutu, predstavlja pokušaj utvrđivanja stvarnog stanja sela nakon tog razdoblja.

Uz grupu koja je radila na Sociologiji sela manji se broj suradnika Agrarnog instituta bavio i ekonomikom poljoprivrede. Najistaknutiji među njima bio je Zvonimr Baletić, koji se bavio prvenstveno tržištem poljoprivrednih proizvoda. Poliglot, pratio

3 Stanujući kraj Zapadnog kolodvora u Zagrebu svako sam jutro gledao stotine, a možda i tisuću radnika, kako stižu oko 5.30 sati ujutro zagorskim vlakom i onda polako, u kolonama, idu raditi (počinjalo se u 6 sati ujutro) u Franck, HPS-pamučnu predionicu i Plivu.

${ }^{4}$ Prvi seljaci koji su dospjeli u parlamente prije I. svjetskog rata stigli su u Srbiju 1905. godine (u ime stranke Srpska narodna seljačka sloga); u Hrvatski sabor ulaze 1906. godine dva seljačka predstavnika (u ime Hrvatske seljačke stranke). U ustavotvornoj skupštini Kraljevine SHS bilo je 98 „zemljoradnika“ (od 419 poslanika). U parlamentu socijalističke Jugoslavije 1974. - 1978. samo je jedan poljoprivrednik (i to vinogradar iz Slovenije!). 
je stranu literaturu i časopise već od prvog broja Sociologije sela (Henry Mendras, B. Gallski, H. Cholay, T. Schultz bili su predmetom njegovih prikaza autora, a od časopisa Études rural i Journal of Farm Economics) upozoravajući domaću javnost s iznimno vrijednim autorima i radovima s područja ekonomike poljoprivrede. Prevodio je, također, u okviru svog rada u Institutu vrijedne radove, od čega posebno ističem prijevod rada M. Pohorillea o cijenama poljoprivrednih proizvoda i tržištu 5 . Daljnji životni put Zvonimira Baletića, od asistenta do redovitog profesora i akademika, potvrđuje vrsnoću kadrova koji su radili u Agrarnom institutu.

U Agrarnom je institutu i Krešimir Pažur, koji će baveći se specifičnom djelatnošću poljoprivrednih gospodarstava (ribnjačarstvo) ostvariti uspon do prvog stručnjaka na tom području. U radu Instituta sudjeluju i Franjo Kamenečki (iako je bio zaposlen u Zavodu za unapređivanje zadružne poljoprivrede pri Glavnom zadružnom savezu NRH i Visokoj privrednoj školi) i Vladimir Stipetić. U to se vrijeme bavim prvenstveno napuštanjem modela Preobraženskog, po kome je poljoprivreda, putem škara cijena, glavni izvor akumulacije za industrijalizaciju što donosi prelazak na tržišnu industrijalizaciju i gospodarstvo. Pišem o novim tendencijama do kojih dolazi jačanjem tržišnih zakonitosti u nas i, obrnuto, što tržište postavlja kao zadatak pred strukturu proizvodnje. Međutim informacije koje skupljaju i analiziraju suradnici iz ruralne sociologije omogućuju mi i da zatražim izmjene u politici prema seljaku6.

Završio bih ovo razmatranje Agrarnog instituta početkom šezdesetih godina kao osnivača Sociologije sela. Taj je časopis svojim 50-godišnjim izlaženjem dokazao opravdanost svog osnivanja i afirmirao sociologiju sela kao disciplinu u nas.

5 Meni su radovi tog poljskog ekonomista bili i metodološki i načelno iznimno korisni pri pisanju knjige Jugoslavensko tržište poljoprivrednih proizvoda (Zadružna knjiga, 1964.), prve knjige koja je obrađivala fenomen poljoprivrednog tržišta u bivšoj državi.

6 Posebno sam te probleme obrađivao u studiji „Razmatranja o jugoslavenskom tržištu prehrambenih proizvoda u razdoblju 1956. - 1961.“, Ekonomski pregled 10-11/1962. i „Konkretizacija i realizacija programski prihvaćenih dokumenata o našoj politici u poljoprivredi“, Ekonomski pregled 1/1966. 